\title{
European economies suffer a crisis of combination
}

\section{Noralv Veggeland}

Inland Norway University of Applied Science, Postboks 400, 2418 Elverum, Norway

Professor of Public Policy

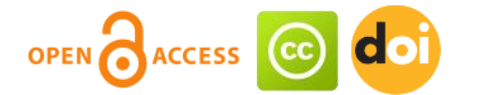

Article history:

Received: February 15, 2018

1st Revision: March 5, 2018

Accepted: March 25, 2018

\section{JEL classification:}

H12

E12

P16

DOI:

10.14254/jems.2018.3-1.6

\begin{abstract}
In Europe, where the financial crisis was transformed into national debt crises in several countries, the current phase of the denial cycle marked by an official policy approach predicated on the assumption that normal restored through a mix of austerity, privatization and less state involvement came through (anti-Keynes). The other view is this. Governmental investments - and financial decisionmaking to regulate the effective demand in national economies is based on the basic principles introduced by John Maynard Keynes in his 'General Theory of Employment, Interest and Money (1936). The solution of the temporary crisis of the democratic capitalism might be linked to Keynes by his successors the neoKeynesians. However, the representative democracy has become weak and fragmented, and under control of international powerful multinationals. The citizens not any longer look upon their national government as their representatives but as representatives for interest of foreign states and international organizations. Poor public politics and policy of austerity generating a crisis of combination are what come out of it.
\end{abstract}

Keywords: Regulation, Keynesianism, financial crisis, poor politics.

\section{Introduction}

The political German scientist Wolfgang Streeck writes in the Le Monde Diplomatique, January 2012 that "Every day we read in the newspapers that the markets dictate what sovereign and democratic states can do and what they cannot do for their citizens. The consequence is that the citizens not any longer look upon their government as their representatives but as representatives for interest of foreign states and international organizations". This is a correct statement. It is not the market that directly dictates governments, that is what deregulation of markets does. Let's have an analysis of the issue. 


\section{Basic material throwing light on the crisis issue}

There is a close relation between the development of the modern western regulatory state and the process of creating markets and correcting markets in terms of Giandomenico Majone's conceptualization of the regulatory state (Majone, 1994, 1997, 2003). It is regulations to accomplish these goals, both nationally and internationally, that dictate governments. The European Union dictates the government of the member states. So does membership of the World Trade Organization (WTO). National impotence is the outcome of the huge amount of worldwide market agreements (Veggeland, 2009).

USAs depth of state is more than about 2860000 billion dollar in foreign loans, and President Donald Trump has additionally promised a gigantic investment program. If implemented on future infrastructure like roads and railways and walls, the loans certainly will increase dramatically. This program means new huge extra loans. Financial crisis and recession dominates the Western capitalism of our time. The crisis in the Euro-zone is evidently a grave blow to European integration, but intimately connected to the international financial crisis. The collapse of the national state finances understood as a manifestation of a fundamental mechanism in the capitalistic system, where un-balance and un-stability is the rule instead of the opposite. The Western democratic capitalism has in the year after the Second World War, went through three crises and conflicting phases, and is now going through a fourth one. For the EU, additionally, the Great Britain is getting out as a member state, Brexit, and the huge refugee problem generates a pressure, which is waiting for an expensive solution.

In Europe, where the financial crisis transformed into national debt crises in several countries, the current phase of the denial cycle marked by an official policy approach predicated on the assumption that normal restored through a mix of austerity, privatization and less government involvement came through (anti-Keynes). The claim is that advanced countries do not need to apply the standard tool it used by emerging markets, including debt restructurings, higher inflation, capital controls, and significant financial repression. Advanced countries do not resort to such gimmicks, policymakers say. To do so would be to give up hard-earned credibility, thereby destabilizing expectations and throwing the economy into a future vicious circle. Although the view that advanced country financial crises are completely different, and therefore should be handled completely differently, has been a recurrent ideological refrain, notably in both the European sovereign debt crises and the U.S. subprime mortgage crisis, this view is at odds with the historical track record. In most advanced economies, based on Keynesianism, state intervention, debt restructuring or conversions, financial tools, and higher inflation have been integral parts of the resolution of significant debt overhangs.

The after war period of economic crises started with 1) the stagflation crisis of the 1970s. Afterward came 2) a public deficit crisis up, followed by 3) a privatized deficit crisis. Today the phase forth is ruling consisting of both 4) a public and a privatized deficit crisis, a combination crisis. Adequately three solution to crises has been tested out with conditional success, and a forth solution is by now implemented. What we know is that every one of the solutions of the crises using traditional tools has led up to the next following crisis (Veggeland ed., 2016).

The US economist, Raghuram G. Rajan, puts weight on the cultural aspect of the financial crisis, and figures out what he call 'Fault Lines' (2010). He points out powerlessness and the absence of coherence in the US democratic capitalism. His explanation puts weight on the catastrophic development of economic and social inequality. Inequality occurring as a crisis in many Western countries, with the USA as the leading nation in that sense, We have mentioned the risky behavior of the banks and heavy private loan taking leading to the financial crisis, and Rajan relates this development to the situation in the USA. This behavior he looks upon as only the last step in the process we have described a process with a wrong course by political powerlessness in an environment of globalized and steady more uncoordinated world.

\section{Some findings}

Justice as a cultural matter and the fact that the citizens believe the government as the guarantee for democracy is neglected. Rajan points out that for every single dollar in salary growth between 1976 and 2007 went $58 \%$ of that growth to the one richest percent of the families in USA. He continues to tell us that the income of the social middleclass and the poor labor class has stagnated or decreased, while the income of the richest $10 \%$ arose enormously. This development created a sort of disorder neglected by the politician, but obviously disturbed the legitimacy of the politics. Rajan shows that this dilemma got politicians to compensate for the occurrence of inequality and the threat to their legitimacy, by voting forward liberalization of the credit market 
and favoring consume financed by loan. He writes that politicians, always is sensible to their electorate, are choosing what they think as a solution of universal impact, namely to secure cheap loans to them suffering for not having participated in the growth of the economy and its outcome. The banks took the advantage of the situation to earn money of suspect real estate loans, namely subprime loan. The real estate market was for a while a hot spot in its function, realizing products to constantly higher prizes. People bought housing products characterized by steadily rising prizes, believing that the prizes would continue to rise - into heaven. High risk taken in this unregulated financial game. When the US Federal Reserve Bank let the interest on loan arise a bit, steadily more people were not able to upkeep their loans, i.e. pay part payment and interest rates. Accordingly, the banks shaken and threaten by going bankruptcy and did so. The Financial crisis spread worldwide after the $2007 / 2008$.

The crisis that concerns the USA, EU and other Western countries is today what we might call a crisis of combination linked to both public and privatized loan and national budget deficits, for example look to Greek, Spain and Portugal. To get through this crisis the governments of these countries insist on budget cuts and saving programs, and cuts in salaries and pension arrangements. The impact of these actions is reduced market demand, which boosts the crisis in terms of rising unemployment. A natural consequence of this is social and political disturbance visible in many European countries. Wolfgang Streeck (2012) concludes: 'The crisis of today threatens the democratic order as much as the economic order, maybe even more'. As in the past, the crisis will find a provisional solution. Most likely, the crisis of combination this time will not favor the interests of speculative financial actors, which probably will become subordinated stronger international regulations, in Europe of the EU. (In the USA with the new President Trump with his buzzword "America First" nobody knows the way out.) The interests will remain, but expand their self in tight contact with the real capital, i.e. in contact with global industrial monopoly interests. Consequently, the citizens will to an even lower extent look upon their government and politicians as representatives and guaranty for democracy.

\section{Discussion; the democratic capitalism and the neo-Keynesian explanation on the crisis of combination}

Governmental investments - and financial decision-making to regulating the effective demand in national economies is based on the basic principles introduced by John Maynard Keynes in his 'General Theory of Employment, Interest and Money (1936), An explanation on the temporary crisis of the democratic capitalism linked to the Keynesian tradition must contain the following factors (Veggeland ed., 2016):

Firstly, a central point in Keynesian theory was arguments for an active state whose main role was to correcting markets and to stabilizing economic circulations. - We have described and analyzed the stagflation crisis of the $1970 \mathrm{~s} / 80 \mathrm{~s}$ and found that the state remained active. The Western governments chose comprehensive public loan taking and the issuing of government bonds, which later on got the consequence of a public crisis of credit.

Secondly, by using the term 'inclination' to consume, Keynes was able to explain how the consumption behavior changed its character parallel to changing prizes in the market, in our case in the housing market. When the prizing of real estate rises, an inclination arises which generates a feeling of value gain, which turns into a feeling of saving money. Further on this turns into increasing consume because it is believed that the 'savings' are available right there. This is the background for the development of what we have called the privatized credit crisis as a follower of the public credit crisis. The Government liberalized the financial markets, and the inclination to finance consume by loans increased. The inclination mostly created and inspired by the arising prizes in the housing market, and the false feeling of thereby saving money. When the housing bubble cracked, it became clear that the saving was not real.

Thirdly, Keynes argued that financial melting down and the crack of aggregated demand in the economy closely related to upcoming inequality of income and stagnation in salary payments. The government compensated by liberalization of the financial policy and expanded its loan reserves in order to keep the welfare state going by redressing social problems with arrangements of support, guarantees and access to privatized loans. - What we call the crisis of combination does explain by this kind of Keynesian argumentation. While the net salary of 90 percent of the population changed very little during the last 20 years, the housing prizes have grown enormously in the same period. It is this reality that Rajan's 'Fault Lines' describes and analyzes. It is all about this. Selling real estate gave a surplus, which generated an inclination to higher consume in this market. Public and privatized crises of credit combined; public loan taking to pay welfare followed by a privatized crisis of credit. The EURO zone of the European Union (EU) hit by a crisis as a 
follower of the financial crisis. The EU, the European Central Bank (ECB) and the International Monetary Fund (IMF) chose a strategy to press national governments to cut welfare arrangements to prevent states to go bankruptcy; examples are what happen in countries like Greece, Spain, Portugal, Italy, Hungary and others. The privatized inclination to loan taking stopped by claiming a higher level of guarantee to get such loans.

We might describe the situation characterizing the Western democratic capitalism of today, involving three variables. High level of loan (Germany an exception) taking and aggregated consume generated a situation of low employment. During the crisis of combination of public and privatized credit crisis the unemployment rate will increase as time pass on. By necessity the inclination to public and private consume will be shrinking caused by mutual dependency between the variables. The inclination to the crackdown of aggregated demand and the growth of unemployment is strengthening by strong budget regulations and pay back of public loans. This situation occurred in the Euro-zone countries and hit them both economically and politically. In terms of Keynesian theory, the effective demand will decrease in the national economies. This triggers a negative economic spiral with growing unemployment followed by a corresponding decrease in purchasing power. When the national GNP begins decreasing it triggers printing of money, and the economies get threatened by increasing inflation. In the EU the European Central Bank (ECB) is very much aware of this mechanism, and keep on to implement a strong monetary policy in the Euro-zone. The other side of the coin is the grave impact of this policy on the Mediterranean countries already hit by the crisis of the capitalism. In the Eurozone, no one of its member states is allowed to devaluate its currency (Euro) in their endeavor to win more competitive ability in the world market. Low inflation rate makes loan does fall regarding nominal value. Consequently, the unemployment rate continues to rise followed by social and political disorder in the European countries mentioned. The crisis is most likely spreading to other countries as well.

Accordingly, a temporary respond in Europe seems to be on the one hand to increase the effective demand by import 1) capital from outside Europe to compensate for internal public loan taking. Such capital could come from the growing economies of the so-called BRICS countries, i.e. Brazil, Russia, India, China and South Africa. USA experiences a solution to the financial crisis by being a market for Chinese export whose payment remains as loan but with US dollar as involved currency in the business transactions. Regarding President Trump, he has announced an end to this, and China will response in a long-term way we so far do not know. 2) Dollar are printed and put into the money circulation, but inflation fails to appear because of US dollar as a global currency regarding economic transactions.

On the employment side decreasing consume might be avoided by giving the salaries of the labor force an upheaval. Increasing demand and consume will be an immediately output of the strategy, this deduced from the Keynesian analyses of inclination. The understanding of the combination crisis in the democratic capitalism is detained with a failure when it is explained as a crisis caused by an expensive welfare state together with public loans taken up to restore and pay for the services of the welfare state. Even the consideration of making the financial crisis part of the general housing policy and the political wish to make people owners of their own housing facilities is detained with failure. Rather, the explanation belongs to the absence of Keynesian theory and its recommendation of governmental interventions when crisis hit the economic circulation in the capitalistic economy.

Shaping economic politics represents political choices. To go for a liberalized market economy generate consequences very much different compared to them generated by Keynesian strategies. The Nobel Prize winner in economy, Paul Krugman, has named the period between 1950 and 1972 "the period of compression (2007). The Keynesian principles dominated and pressed the market and the state together in a cooperative order. The unemployment was low and the inflation under control. Interventions of the government adjusted the market, and the building of the appreciated welfare state was the final outcome.

In contrast to this situation, Krugman says, that the period since 1980 characterized by divergence; the state has withdrawn from the marked and become a regulatory state, while the market forces were given freedom to develop and expand, only limited and in interplay with judicial regulations. The period characterized by high unemployment, but with inflation under control. This control came up due to the monetary political strategy whose main objective was fighting inflation. The salaries of ordinary people in the democratic capitalist countries went into a race to the bottom, and the trade unions lost power and influence in the economic and political games. This form of governance under former Prime Minister Margaret Thatcher in the UK and former President Ronald Reagan in the USA is well known. 


\section{Conclusions}

Since the 1980s fragmentation of governance regimes has been a dominant development trend due to steering principles deduced from New Public Management theories. The representative democracy has become weak and fragmented and under control of international supranational citizens not any longer look upon their government as their representatives but as representatives for interest of foreign states and international organizations". Poor public politics and policies are what come out of it.

Two cases show that the people of Great Britain voted no stay as a member of the EU, and with Brexit as the consequence. The majority of the citizens wanted their country to be independent and national with benefits to the depth-dependent part of the people, caused by the foreign regulatory power of the EU. In the USA the people elected the rude businessman Donald Trump as their President with a hope that he could bring them better living conditions with his turn-around economic policies and turn to nationalism; "America first". The similarity between the two cases was the belief of the citizens that not any longer could the government be looked upon "as their representatives but as representatives for interest of foreign states and international organizations" - respectively UK the EU and USA China, Mexico and multinational trade agreements.

\section{Appendix A. Supplementary material}

Supplementary data associated with this article can be found, in the online version, at https://dx.doi.org/10.14254/jems.2018.3-1.6.

\section{Funding}

The authors received no direct funding for this research.

\section{Citation information}

Veggeland, N. (2018). European economies suffer a crisis of combination. Economics, Management and Sustainability, 3(1), 65-69. doi:10.14254/jems.2018.3-1.6.

\section{References}

Krugman, P. (2007). The Conscience of a Liberal. New York: W.W. Norton Company.

Majone, G. (1994). The rise of the regulatory state in Europe. West European Politics, 17(3), 77-101.

Majone, G. (1997). From the positive to the regulatory state: causes and consequences of change in the mode of government. Journal of Public Policy, 17(3), 139-89.

Majone, G. (2003). The Politics of Regulation and European Regulatory Institutions. Op.cit. Hayward, J. and Menon, A. (eds.) (2003: 297-312).

Rajan, R. G. (2010). Fault Lines: How Hidden Fractures Still Threaten the World Economy. Princeton: Princeton University Press.

Streeck, W. (2012). The Burden of Depth, Le Monde Diplomatique Jan. 2012.

Veggeland, N. (2009). Taming the regulatory state: Politics and ethics. Cheltenham, UK and Northampton, MA, US: Edward Elgar Publishing.

Veggeland, N. (ed.) (2016). The Current Nordic Welfare Model, New York: Nova Science Publishers.
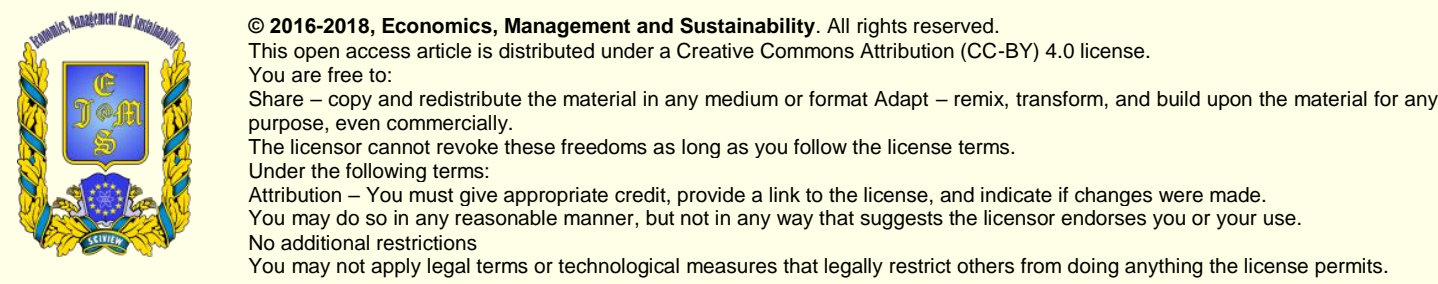

Economics, Management and Sustainability (ISSN: 2520-6303) is published by Scientific Publishing House "CSR",

Poland, EU and Scientific Publishing House "SciView", Poland

Publishing with JEMS ensures:

- Immediate, universal access to your article on publication

- High visibility and discoverability via the JEMS website

- Rapid publication

- Guaranteed legacy preservation of your article

- Discounts and waivers for authors in developing regions

Submit your manuscript to a JEMS at http://jems.sciview.net or submit.jems@sciview.net

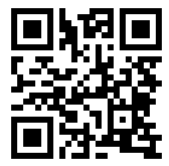

